\title{
PELOS FIOS DA MEMÓRIA: INFÂNCIA E ANCESTRALIDADE EM PONCIÁ VICÊNCIO
}

\author{
Through the threads of memory: childhood and ancestry in Ponciá Vicêncio
}

\author{
Elisângela da Silva Santos \\ http://orcid.org/0000-0003-2401-9999 \\ Universidade Federal de Goiás/Jataí, Unidade Especial de Educação, Jataí, GO, Brasil. \\ 75804-020 - uaeeducacao.jatai@ufg.br
}

\begin{abstract}
Resumo: A escritora mineira Conceição Evaristo traz como marca a produção literária nascida da experiência de vida do sujeito negro na sociedade brasileira, o que abala a estruturas e padrões literários hegemônicos. Neste artigo, discute-se a temática da infância na obra de Conceição Evaristo, Ponciá Vicêncio, que também pode ser lida como uma quebra de padrões ao oferecer protagonismo à criança. Como veremos, neste romance, a infância das personagens, transita historicamente entre passado e presente, descrevendo as diferentes formas de aprendizagem, brincadeiras, fantasias, violência e opressão, em consonância com a herança identitária das personagens, que adultas repensam o olhar e o sentir da criança. Numa sociedade que prioriza o olhar do adulto experiente, a criança pequena e negra, adquire centralidade e pode narrar seus percursos, a partir da sua condição social, racial e também de gênero. Como se observará, uma crítica social ao passado escravista perpassa todo o livro. O romance é constituído a partir de uma estrutura sinuosa, uma vez que sua leitura depende das lembranças da personagem principal, que ingressa em diversos labirintos até encontrar uma saída para seu sofrimento e inanição, diante da situação de desigualdade social e racial vivenciada por ela e por sua família. Neste sentido, Evaristo nos apresenta a possibilidade de pensar a infância de maneira plural, pois nos convida a repensarmos na concepção do que é o universo infantil para além da inocência, do paraíso perdido, dos brinquedos coloridos, e dos bancos escolares normatizadores.
\end{abstract}

Palavras-chave: Ponciá Vicêncio. Infância. Memória. Ancestralidade. Identidade.

Abstract: Conceição Evaristo, a writer from the State of Minas Gerais, brings as her mark the literary production born out of the life experience of the black person in Brazilian society, which shakes hegemonic literary structures and patterns. It is discussed in this article the thematic of childhood in the work of Conceição Evaristo, Ponciá Vicêncio, which can also be read as a breaking of standards by offering prominence to the child. As we will see, in this novel, the childhood of the characters transits historically between past and present, describing the different forms of learning, the games and frolics, fantasies, violence and oppression, in consonance with the identity inheritance of the characters, that, once adults, rethink the child's look and feelings. In a society that prioritizes the point of view of the experienced adult, the small black child acquires centrality and is able to narrate the own paths, from their social, racial

Esta obra está licenciada sob uma Creative Commons - Atribuição 4.0 
status and also their gender. As will be seen, a social critique of the slave-making past permeates the whole book. The novel is constituted from a sinuous structure, since its reading depends on the memories of the main character, who enters in several labyrinths until finding an exit to its suffering and prostration before the situation of social and racial inequality experienced by her and by her family. In this sense, Evaristo presents us the possibility of thinking infancy in a plural way, for it invites us to think twice about the conception of what the children's universe is, beyond innocence, lost paradise, colorful toys, and standardizing school desks.

Keywords: Ponciá Vicêncio. Childhood. Memory. Ancestry. Identity.

\section{"Lá estava sua a sua menina única e múltipla"}

Este texto tem como proposta analisar a infância na obra Ponciá Vicêncio originalmente publicada em 2003, pela escritora Conceição Evaristo (1946-). Trata-se de um romance composto por pequenos capítulos narrados em terceira pessoa, que conta a "jornada vital" de Ponciá Vicêncio e de sua família, constituída por sua mãe, Maria Vicêncio, seu irmão Luandi, seu pai e seu avô, Vicêncio. A narrativa desse livro não obedece a uma linearidade cronológica, ou seja, a história não parte da infância dessas personagens e atingem à idade adulta delas, sim, depende das diversas memórias resgatadas pela personagem principal, que "emendava um tempo ao outro" através de suas lembranças.

A família de Ponciá foi constituída na Vila Vicêncio, povoado localizado nas terras dos herdeiros do escravocrata Coronel Vicêncio, ali a personagem principal viveu até os seus 19 anos de idade, quando partiu para a cidade, uma decisão que viera forte e repentina, já que não suportava mais viver a situação de penúria e humilhação que vivia no campo.

Para a exposição do argumento principal do artigo, o texto contemplará os seguintes temas: o início da viagem de retorno da personagem principal, que desolada e vivendo sob uma condição social precária decide voltar para a casa de sua família, como veremos, esse retorno inicialmente ocorre pelas suas lembranças do passado; o território da infância da obra, acessado pelas reminiscências de Ponciá Vicêncio, que ao rever o período em que era criança, também revê as infâncias sofridas de seu pai e de seu irmão, marcadas pela condição da criança negra que sempre tiveram que trabalhar como adultos, por fim, discutimos a origem e consequência do sobrenome Vicêncio, uma marca direta na família do período escravocrata brasileiro.

\section{Ponciá Vicêncio e a busca de si}

A narrativa começa a ser desenrolada quando Ponciá já vivia na favela, momento que sentiu repentinamente a vontade de voltar ao seu lugar de pertença, e reunir-se novamente com sua família, elo quebrado desde quando saiu do povoado. Quando ela vai se lembrando de todos, inclusive do avô, que morrera quando Ponciá era apenas um bebê, mas mesmo assim o vô Vicêncio desempenhará relevante papel na constituição de sua identidade.

Conforme o crítico Eduardo de Assis Duarte (2006), a autora retoma nessa obra o procedimento do "brutalismo poético" ao narrar, numa linguagem concisa e densa de sentido a 
vida de uma mulher oriunda de um mundo rural, desde a infância até a "maturidade" desterritorializada na favela em que vegeta junto ao companheiro. Nesse sentido, a narrativa configura-se como um Bildungsroman (romance de formação ou de educação) feminino e negro, ao dramatizar a busca quase intemporal da protagonista, a fim de recuperar e reconstruir família, memória, identidade.

Este gênero literário que surgiu no Século XVIII na Alemanha, o chamado Bildungsroman, cuja temática principal é a formação do indivíduo. Segundo Mazzari (1999), a tensão dialética inerente a esse gênero está baseada entre o real e o potencial. O romance $O s$ anos de aprendizado de Wilhelm Meister, de Goethe, escrito durante os anos de 1793 e 1795, representa um dos livros mais conhecidos desse gênero.

De acordo com Wilma Patricia Mass (2000), o significado de Romance de Formação corresponde a dois conceitos fundamentais do patrimônio das instituições burguesas. Bildung e Roaman são dois termos que entraram no vocabulário acadêmico na segunda metade do século XVIII. A formação do jovem de família burguesa, seu desejo de aperfeiçoamento como indivíduo, mas também como classe, coincidem historicamente com a "cidadania" do gênero romance.

Trata-se, portanto, de uma instituição social-literárias, composta, por um lado, pelo conceito histórico da Bildung burguesa, fundamental para o funcionamento da sociedade absolutista tardia na Alemanha do final do século XVIII, e, por outro, pela grande instituição literária do mundo moderno, o romance (MASS, 2000, p. 14).

Assis Duarte (2006), comenta que há um ímpeto antropofágico presente na postura de Conceição Evaristo, que rasura esse modelo europeu para conformá-lo às peculiaridades da matéria representada. A narrativa mescla, de forma tensa, passado, presente, recordação e devaneio. Trata-se de uma descendente de escravos africanos, e essa herança marcante na linhagem memorialística existente na literatura afro-brasileira, que reflete sobre os despojados da liberdade, mas não da consciência.

A fala diaspórica desses condenados da terra se articula de forma sincrônica e a posteriori, desconhecendo a encarnação do espírito de nacionalidade que marca boa parte da literatura canônica [...]. A narrativa de Conceição Evaristo filia-se, portanto, a esse veio afrodescendente que mescla história não oficial, memória individual e coletiva com invenção literária. (DUARTE, 2006, p. 307).

Conceição Evaristo possui participação ativa nos movimentos de valorização da cultura negra no Brasil, sua literatura traz como marca a condição da mulher negra na sociedade brasileira, e se quisermos estender, também traz como marca a condição da criança negra, já que como apontou Priore (2013), a história das mulheres não é só delas, é também a da família, das crianças da literatura, do seu corpo, da sua sexualidade e da violência que sofreram e praticaram.

Octávio Ianni (1988), sublinha que o negro é o tema principal da literatura negra. Sob

Anu. Lit., Florianópolis, v. 24, n. 2, p. 42-58, 2019. ISSNe 2175-7917 
muitos enfoques, ele é o universo humano, social e cultural que nutre essa literatura.

Naturalmente o negro sempre implica no branco, no outro do negro senhor de escravos, capataz, feitor, fazendeiro, empresário, empregado, funcionário, operário, lavrador, político, governante, intelectual e assim por diante. Implica na escravatura, época colonial, período monárquico, várias repúblicas, várias ditaduras, urbanização, industrialização, formas de trabalho e vida. Compreende diversidades, multiplicidades, desigualdades, antagonismos. Mas não há dúvida de que o negro brasileiro é tema principal dessa literatura. (IANNI, 1988, p. 92).

O livro Ponciá Vicêncio tem como personagens negros brasileiros, que passaram pela experiência da escravidão, sendo os confins da memória da personagem principal, que busca necessariamente retomar sua ancestralidade, o fio condutor que revela as consequências de um Brasil escravocrata na vida de adultos e crianças.

A obra não está voltada para a perspectiva da literatura infanto-juvenil, no entanto, a narrativa reacende acontecimentos nas vidas de seus personagens centrais que marcaram suas trajetórias, portanto, o tema da infância está presente na obra. As crianças se configuram de diferentes maneiras, ora representam o aspecto fantasioso e "ingênuo" de observação do mundo, ora estão inseridas no contexto da violência que a situação racial e social brasileira as insere. Ao trazer o tema para o centro da narrativa, Conceição Evaristo fornece a possibilidade de o leitor observar as transformações que o país passou a partir da vivência de duas gerações de crianças negras representas na obra de maneira centralizada, justamente num país onde a representação da criança negra é ainda muito problemática.

Na perspectiva de Assis Duarte (2009), trata-se de uma literatura que narra a história de superação vinda dos antepassados, a partir de uma perspectiva identificada com a visão do mundo e com os valores do Atlântico Negro.

Nesse sentido, houve uma valorização das experiências infantis, pois a narrativa confere essa possibilidade, e nos permite adentrar em episódios pouco frequentados na análise da literatura brasileira. Anderson Mata (2015), aponta que é comum que ao lado de uma crítica social ou de uma descrição dos costumes exista uma tensão simbólica ou alegórica, que posiciona a infầncia como um "significante relacionado a múltiplos significados" (MATA, 2015 , p. 15). O que seria uma herança do pensamento romântico, pois nessa perspectiva a personagem infantil carrega o fardo de representar a inocência ou a sabedoria, ou o novo ou a promessa de futuro, ou a combinação dessas variáveis.

Esse movimento, ao mesmo tempo que pode levar ao esvaziamento da dimensão política do texto que daria como a crítica, articulada pela tematização, do lugar social da infância, tem o condão de garantir maior gravidade (e importância) à infância enquanto tópico, agora transformada em topo. (MATA, 2015, p. 15).

A noção de infância representada em Ponciá Vicêncio não é aquela atrelada ao desenvolvimento psicológico individual da criança, sim é discutida em sua trajetória histórica, social, política e cultural. 
Essa perspectiva narrativa pode ser analisada a partir do referencial teórico da Sociologia da Infância, que ao referendar a fala e a participação da criança, inverte os processos de subalternização. Abramowicz (2011), aponta que não existe algo na fala das crianças que seja excepcional ou diferente, mas a criança ao falar, faz uma inversão hierárquica discursiva, pois falas não consideradas com frequência, são consideradas.

A criança negra (única e universal) que nasce e inscreve em si o passado de sua raça, de sua história, já carrega suas inscrições, mas também traz em si uma criança (singular e múltipla), ou seja, a criança é, também uma multiplicidade de tempo. Assim uma criança é ao mesmo tempo universal, individual e singular. (ABRAMOWICZ, 2011, p. 20).

Nesse sentido, é importante ressaltar que a experiência da infância se diferencia conforme categorias sociais definidoras da identidade infantil. Maria Cristina Gouvêa (2000), aponta que a literatura de ficção possui particularidades, e pode trazer a infância como personagem e como tema de reflexão, bem como tornar a infância como objeto de análise ${ }^{1}$.

Assim, acreditamos que ao propor uma análise das infâncias na obra de Conceição Evaristo, poderemos observar o processo de construção e reconstrução das memórias das complexas personagens que compõe o mosaico familiar de Ponciá Vicêncio.

\section{O território da infância em Ponciá Vicêncio}

A cena de abertura do livro relembra o medo que a personagem principal teve durante toda sua infância, o de passar por debaixo do arco-íris, pois diziam que menina que passasse por baixo do arco-íris virava menino, no entanto:

Naquela época Ponciá Vicêncio gostava de ser menina. Gostava de ser ela própria. Gostava de tudo. Gostava. Gostava da roça, do rio que corria entre as pedras, gostava dos pés de pequi, dos pés de coco-catarro, das canas e do milharal. Divertia-se brincando com as bonecas de milho ainda no pé. Elas eram altas e, quando dava o vento, dançavam. Ponciá corria e brincava com elas. O tempo corria também. Ela nem via. O vento soprava no milharal, as bonecas dobravam até o chão. Ponciá Vicêncio ria. (EVARISTO, 2017, p. 13).

Interessante observar que a narrativa estabelece como ponto de partida o feminino; no decorrer do livro, percebemos a importância dessa assertiva no processo de formação da personagem. Ademais, o fato de ser mulher, legou a Ponciá o ônus e o bônus de viver sob essa condição. Nessa passagem citada lemos o indivíduo integrado ao seu lugar de pertencimento, pois gostava da roça, do rio, de ser menina, gostava de tudo. Resgatar esse período em que estava sob a proteção e afeto de sua família, cercada por seus brinquedos e brincadeiras, demonstra a vontade de Ponciá reconciliar-se com sua tradição harmoniosa que possuía quando era criança.

Em muitos momentos em que aparece lembrando-se de suas aventuras infantis, Ponciá

\footnotetext{
${ }^{1}$ Exemplo disso é o trabalho de Maria Lúcia de Barros Mott (1979) no texto "A criança escrava na literatura de viagens".
} 
desvenda ao leitor suas esperanças e medos, num período organizado a partir de determinantes sociais. Na maioria das vezes, ela brincava sozinha, pois o irmão Luandi, por ser homem, precisava aprender o ofício da lavoura com o pai, enquanto a menina permanecia em casa, recolhida aos cuidados e olhares de mãe, com quem aprendia a fazer artesanatos com o barro.

Fora criada sozinha, só com a mãe. Tinha mais um irmão que pouco brincava com ela, pois acompanhava o pai no trabalho da roça, nas terras dos brancos. Ela e a mãe ficavam dias e dias sem ver os dois. Nos tempos das chuvas as visitas deles rareavam mais ainda. A mãe fazia panelas, potes e bichinhos de barro. A menina buscava argila nas margens do rio. Depois de seco, a mãe punha os trabalhos para assar num forno de barro também. As coisinhas saíam duras, fortes, custosas de quebrar. (EVARISTO, 2017, p. 20).

Nesta passagem, observa-se a solidão da criança, que crescia sozinha, sem nenhuma intimidade com o irmão ou outra criança da vizinhança, ela se divertia brincando com as bonecas de milho ainda no pé, até que um dia confidencia à mãe que havia visto uma mulher alta e transparente, a mãe assustada "corta o mal pela raiz" ao mandar o marido cortar o milharal. Ponciá chorou, pois sentiu um vazio por não ter mais suas espigas para brincar de boneca.

E quando Ponciá Vicêncio acordou no outro dia, o milharal estava derrubado. As bonecas mortas pelo chão. Ela ainda olhou para os lados com esperança de ver a mulher alta e transparente. Não viu. Tudo era um só vazio. Ponciá chorou. Nunca mais ela viu a mulher alta, transparente e vazia, que um dia sorria para ela entre as espigas de milho. (EVARISTO, 2017, p. 14).

A indústria "doméstica rudimentar" de brinquedos de Ponciá, para utilizarmos a expressão de Walter Benjamin (2002), foi destruída pela mãe, que temia as visões sobrehumanas da filha, que brincava e se libertava da lógica de mundo adulta. Benjamim (2002), ao comentar a história do brinquedo em sua totalidade, aponta que a partir da segunda metade do século XIX, o brinquedo começa sua acentuada decadência nas sociedades industriais, pois se tornam maiores e foram perdendo aos poucos o elemento discreto, minúsculo, sonhador e sua feitura artesanal. Desse fato, conclui que quanto mais a industrialização avança, tanto mais decididamente o brinquedo se subtrai ao controle da família, tornando-se cada vez mais estranho não só às crianças, mas também aos pais. O brinquedo já desempenhou uma peça do processo de produção que ligava pais e filhos.

O brinquedo, mesmo quando não imita os instrumentos dos adultos, é confronto, e, na verdade, não tanto da criança com os adultos, mas destes com a criança. Pois quem senão o adulto fornece primeiramente à criança os seus brinquedos? E embora reste a ela uma certa liberdade em aceitar ou recusar as coisas, não poucos dos mais antigos brinquedos (bola, arco, roda de penas, pipa) terão sido de certa forma impostos à criança como objetos de culto, os quais só mais tarde, e certamente graças à força da imaginação infantil, transformam-se em brinquedos. (BENJAMIN, 2002, p. 96).

A ligação entre a mãe e filha, na história de Evaristo, está marcada pela produção de peças 
de barro, aspecto que eterniza a relação das duas. As peças eram moldadas em forma de canecas, talheres, pessoas em miniatura, e têm a função de ser o guia do reencontro da família que se apartou, pois Luandi, já adulto e vivendo da cidade consegue localizar primeiramente a mãe e depois a irmã numa feira de artesanato, onde estavam expostas as peças das duas mulheres. E também Ponciá, ao realizar sua viagem de regresso ao povoado, em todas as casas visitadas, encontrou os trabalhos de barro, feitos por ela e por sua mãe.

Durante sua infância, Ponciá não frequentou a escola formal, mas queria muito aprender a ler, quando soube que alguns missionários andavam pelo interior ensinando, a mãe consentiu a filha aprender, já que segundo ela, o saber da cidade era diferente do da roça, sabendo ler, quem sabe a menina não tomaria outros rumos, pois a importância da roça era conhecer as fases da lua, o tempo do plantio e de colheita, o tempo das águas e das secas, as garrafadas, a benzedura, etc.

Ponciá Vicêncio vencia as dificuldades. Aprendeu o abecedário, conhecia as letras em qualquer lugar. Quando o pai chegava, ficavam juntos lendo as letras na cartilha. Enquanto o saber do pai, em matéria de leitura, se estacionara no reconhecer das letras, o da menina ia além. Começou a formar as sílabas e, quando já estava formando as palavras, a missão acabou. Os padres foram para outros povoados, tendo deixado os casais amigados, casados; as crianças pequenas batizadas; as maiores tendo comungado pela primeira vez; e os doentes ungidos. [...]. Quando os padres partiram, depois de terem cumprido todos os seus ofícios, Ponciá logo percebeu que não podia ficar esperando por eles, para aumentar o seu saber. Foi avançando sozinha e pertinaz pelas folhas da cartilha. E em poucos meses já sabia ler. (EVARISTO, 2017, p. 26).

A narrativa estabelece uma relação entre o saber popular e o científico, não de maneira hierarquizada, já que existe o reconhecimento da função do saber prático, oral e tradicional, da experiência que é transmitida de um para o outro.

Mencionando novamente Walter Benjamin (1994), ao discutir a figura do narrador, aponta que o senso prático é uma das características de muitos narradores natos, a narrativa possui a dimensão utilitária. "Essa utilidade pode consistir seja num ensinamento, seja numa sugestão prática, seja num provérbio ou numa norma de vida - de qualquer maneira, o narrador é um homem que sabe dar conselhos". (BENJANIN, 1994, p. 200).

A mãe de Ponciá pode ser lida como a representante da figura do narrador, pois possui a sabedoria e transmite à sua filha, mas entende que a menina precisa se apropriar do saber da cultura letrada, pois imaginava que a filha não ficaria eternamente no povoado, que um dia chegaria sua hora de partir, tanto que quando a menina toma a decisão, ela não a convence do contrário.

Quando Ponciá Vicêncio resolveu sair do povoado em que nascera, a decisão chegou forte e repentina. Estava cansada de tudo ali. De trabalhar o barro com a mãe, de ir e vir às terras dos brancos e voltar de mãos vazias. De ver a terra dos negros coberta de plantações, cuidadas pelas mulheres e crianças, pois os homens gastavam a vida trabalhando nas terras dos senhores, e, depois, a maior parte das colheitas serem entregues aos coronéis. Cansada de luta insana, sem glória, a que todos se entregavam para amanhecer cada dia mais 
pobres, enquanto alguns conseguiam enriquecer todos os dias. Ela acreditava que poderia traçar outros caminhos, inventar uma vida nova. E, avançando sobre o futuro, Ponciá partiu no trem do outro dia, pois tão cedo a máquina não voltaria ao povoado. Nem tempo de despedir do irmão teve. E agora, ali deitada de olhos arregalados, penetrados no nada, perguntava se valera a pena ter deixado a sua terra. (EVARISTO, 2017, p. 30).

Interessante observar que a narrativa destaca os signos da decadência do campo, apontando uma crise entre o Brasil antigo e o moderno; a atitude da personagem ao ir em busca de algo diferente do que vivenciava faz alusão ao indivíduo livre, que tem a consciência de um devir histórico, diferentemente de seus antepassados, que estavam "presos" aquela ordem escravocrata. A modernidade representada pelo trem que avançaria rumo a um futuro citadino que Ponciá um dia acreditou e tinha tido a esperança de ter uma vida melhor, mas a vida na favela ao lado do companheiro violento e também fechado em suas dores, demonstra uma vida de pobreza material e sentimento de abandono e solidão.

A vida na cidade é marcada por outras relações sociais, em que as trocas afetivas e a solidariedade eram muito diferentes do seu povoado. Logo a esperança de ter uma história de final feliz na cidade dá espaço à uma história de solidão, exemplo disso foi sua primeira noite, passada na porta de uma igreja, que agia indiferente com os sem-casa, seguindo a lógica citadina perversa, que Ponciá logo percebeu.

Sentia frio e medo. Aos poucos foi chegando companhia. Mendigos, crianças, mulheres e homens. Vinham alegres, risonhos apesar do desconforto e do frio. Ponciá descobriu alguns deitados, agasalhados em jornais, e sentiu um calafrio. Lembrou dos santos que estavam lá dentro, das velas e dos castiçais, dos vitrais coloridos, dos bancos largos e lustrosos de madeira. Reviu o chão liso, brilhante, quase escorregadio da igreja. Olhou novamente para os lados, todos calmos, muitos até dormindo. Ela abriu a trouxa, tirou o terço de lágrimas-de-nossa-senhora, beijando respeitosamente as contas escuras que se diluíam na cor da mesma noite, benzeu-se e começou a rezar a Ave-Maria. (EVARISTO, 2017, p. 35).

É nessa solidão da cidade que Ponciá sentia saudades do seu tempo de criança, e num movimento de retorno à sua ancestralidade Ponciá retornou ao povoado para reencontrar sua família, mas não achou ninguém, apenas memórias, a casa estava vazia.

Ponciá se lembrou do pai, das ausências dele durante longos períodos de trabalho. Atravessou, depois, as terras dos negros e, apesar dos esforços das mulheres e dos filhos pequenos que ficavam com elas, a roça ali era bem menor e o produto final ainda deveria ser dividido com o coronel. (EVARISTO, 2017, p. 41-2).

As crianças sempre estavam na companhia das mães, essas "mães da solidão" (MATTOSO, 1987), que cuidavam delas para os pais irem trabalhar nas terras dos brancos. Neste momento, a narrativa faz uma crítica muito profunda ao processo de Abolição da escravidão:

Tempos atrás, quando os negros ganharam aquelas terras, pensaram que 
estivessem ganhando a verdadeira alforria. Engano. Em muita pouca coisa a situação de antes diferia da do momento. As terras tinham sido ofertas dos antigos donos que alegavam ser presente de libertação. E, como tal, podiam ficar por ali, levantar moradias e plantar seus sustentos. Uma condição havia, entretanto, a de que continuassem todos a trabalhar nas terras do Coronel Vicêncio. O coração de muitos regozijava, iam ser livres, ter moradia fora da fazenda, ter as suas terras e os seus plantios. Para alguns, Coronel Vicêncio parecia um pai, um senhor Deus. O tempo passava e ali estavam os antigos escravos, agora libertos pela "Lei Áurea", e seus filhos, nascidos do "Ventre Livre" e os seus netos, que nunca seriam escravos. Sonhando todos sob os efeitos de uma liberdade assinada por uma princesa, fada-madrinha, que do antigo chicote fez uma varinha de condão. Todos, ainda, sob o jugo de um poder que, como Deus, se fazia eterno. (EVARISTO, 2017, p. 42).

Marília Ariza (2018), ao analisar a maternidade das mulheres escravas e ex-escravas em São Paulo, na sociedade oitocentista, ressalta que tornar-se livre era certamente uma tarefa, em muitos sentidos, custosa para qualquer sujeito escravizado, mas no caso das mulheres o projeto compreendia adicionalmente imposições específicas da maternidade.

[...] o trabalho árduo e o investimento diurno na formação de poupanças ocupam papel central em alentados projetos de emancipação liderados por mulheres escravizadas e com filhos. Iniciá-los pela manumissão materna era uma opção estratégica que levava em consideração os amplos esforços necessários para a aquisição ou conquista judicial de diversas alforrias. (ARIZA, 2018, p. 153).

A pesquisadora aponta que esse esforço pelo reconhecimento público da maternidade e da família escrava, estava entrelaçado ao contexto de valorização das representações burguesas da maternidade correntes à época. Martha Abreu (1996), chamou atenção para a análise dos debates legislativos em torno da Lei do Ventre Livre (1871), nos quais a maternidade escrava tornava-se plataforma para argumentos contrários e favoráveis à proposta.

Frantz Fanon em Pele Negra, Máscaras Brancas (2008), afirma que na Europa a família representa um mundo que deve ser oferecido à criança. A estrutura familiar e a estrutura nacional mantêm relações estreitas. A militarização e a centralização da autoridade de um país conduzem automaticamente a uma recrudescência da autoridade paterna. Na Europa e em todos os países ditos civilizados ou civilizadores, a família é um pedaço da nação. A criança que deixa o meio familiar reencontra as mesmas leis, os mesmos princípios, os mesmos valores. Não há desproporção entre a vida familiar e a vida nacional. Há uma projeção no meio social das características do meio familiar.

A constatação disso é o inverso no caso do "homem de cor". Uma criança negra, tendo crescido no seio de uma família normal, ficará anormal ao menor contato com o mundo branco. Nas Antilhas, o jovem negro que, na escola não para de repetir "nossos pais, os gauleses", identifica-se com o explorador, com o civilizador, com o branco que traz a verdade aos selvagens, uma verdade toda branca.

Ao mencionar a história da criança negra no Brasil, não se pode ignorar o legado da escravidão, que deixou marcas indeléveis nesta sociedade. Mattoso (1988) apontou que a

Anu. Lit., Florianópolis, v. 24, n. 2, p. 42-58, 2019. ISSNe 2175-7917 
criança negra era um dos seres mais marginalizados no mundo escravista. Isso se reflete na dificuldade de se encontrar fontes documentais que expressem os testemunhos desses indivíduos.

Embora no Brasil da época, principalmente nas classes dominantes, a criança é príncipe, na verdade, o que sabemos da criança escrava? É evidente que a minha indagação refere-se à criança como ser social, como integrante de uma comunidade da qual é membro à part entière, e que dela recebe proteção e abandono. (MATTOSO, 1988, p. 39, grifos do autor).

A escola também se configurou no ideário da população como um espaço demarcado e segregado, frequentado pelos brancos, no entanto, os trabalhos de Marcus da Fonseca (2011) vem apresentando um panorama distinto, uma vez que apontam que a Lei do Ventre Livre (1871) criou algumas possibilidades para que as crianças nascidas de mulheres escravas recebessem algum tipo de formação no nível institucional.

$\mathrm{Na}$ obra Ponciá Vicêncio, a personagem revive essa experiência de seus antepassados no momento que retornou ao povoado, anos após deixá-lo, e percebe que poucas coisas se alteraram nesse espaço.

Ponciá teve a impressão de que havia ali um pulso de ferro a segurar o tempo. Uma soberana mão que eternizava uma condição antiga. Várias vezes seus olhos bisaram uma imagem de uma mão negra rodeada de filhos. De velhas e de velhos sentados no tempo passado e presente de um sofrimento antigo. Bisaram também a cena de pequenos, crianças que, com uma enxada na mão, ajudavam a lavrar a terra. (EVARISTO, 2017, p. 42-43).

Luandi, irmão de Ponciá, trabalhava desde muito cedo nas terras dos brancos, diferentemente da irmã, não aprendera a ler e não tinha tempo para as brincadeiras, sendo a única distração as bonitas cantigas que entoavam como cantos de trabalho junto ao pai. Todas essas lembranças foram a companhia de Ponciá naquela noite que passou sozinha em sua antiga casa. Por onde passava, encontrava rastros de sua família, revia os trabalhos de barro que ela e a mãe faziam. Foi uma vigem de redescoberta, procurava algo perdido, queria reconciliar-se consigo e com o local.

Ela reencontrou a herança do avô Vicêncio: uma imagem de um homem de barro com o braço "cotó", guardado no fundo do baú de madeira, que ela havia feito quando era criança, à época a mãe assustou com a criação da filha.

O que fazer com a criação da filha? O que fazer com o Vô Vicêncio da filha? Sim, era ele. Igualzinho! Como a menina se lembrava dele? Ela era tão pequena, tão de colo ainda quando o homem fez a passagem. Como, então, Ponciá Vicêncio havia guardado todo o jeito dele na memória? (EVARISTO, 2017, p. 20).

A relação entre Ponciá e o avô sempre parecera algo inconcebível para a mãe, pois quando ele morreu ela era apenas um bebê de colo. Para o pai de Ponciá, isso pouco importava, o importante era que ele não parecia o pai. "Não tinha herdado nada do velho e nem queria herdar.

Anu. Lit., Florianópolis, v. 24, n. 2, p. 42-58, 2019. ISSNe 2175-7917 
Aliás, nem sabia se um dia tinha amado ou odiado o pai”. (EVARISTO, 2017, p. 21).

A história da relação de ambos é explicada no momento em que a narrativa desvenda o motivo de Vô Vicêncio ter o braço cotó:

No tempo acontecido, como sempre os homens, e muitas mulheres, trabalhavam na terra. O canavial crescia dando prosperidade ao dono. Os engenhos de açúcar enriqueciam e fortaleciam o senhor. Sangue e garapa podiam ser um líquido só. Vô Vicêncio com a mulher, os filhos viviam anos e anos nessa lida. Três ou quatro dos seus, nascidos do "Ventre Livre", entretanto, como muitos outros, tinham sido vendidos. Numa noite, o desespero venceu. Vô Vicêncio matou a mulher e tentou acabar com a sua própria vida. Armado com a mesma foice que lançara a mulher, começou a se autoflagelar decepando a mão. Acudido, é impedido de continuar o intento. Estava louco, chorando e rindo. Não morreu o Vô Vicêncio, a vida continuou com ele independente do seu querer. Quiseram vende-lo. Mas quem compraria um escravo louco e com o braço cotó? Tornou-se um estorvo para os senhores. Alimentava-se das sobras. Catava os restos dos cães, quando não era assistido por nenhum dos seus. (EVARISTO, 2017, p. 44).

O pai de Ponciá, quando era pequeno não compreendia porque ele teria que permanecer sob a condição de cativo, mesmo sendo livre, mas ao mesmo tempo era um dependente. Ele era pajem do filho do Coronel Vicêncio, e crescera na fazenda, levando a mesma vida de escravo dos pais, quando questionava o pai, este lhe respondia com uma pancada na cabeça, deixando bem clara a impossibilidade de mudar sua condição.

Era pajem do sinhô-moço. Tinha a obrigação de brincar com ele. Era o cavalo em que o mocinho galopava sonhando conhecer todas as terras do pai. Tinha a mesma idade. Um dia o coronelzinho exigiu que ele abrisse a boca, pois queria mijar dentro. O pajem abriu. A urina do outro caía escorrendo quente por sua goela e pelo canto da boca. Sinhô-moço ria, ria. Ele chorava e não sabia o que mais lhe salgava a boca, se o gosto da urina ou se o sabor de suas lágrimas. Naquela noite teve mais ódio ainda do pai. Se eram livres porque continuavam ali? Por que, então, tantos e tantas negras na senzala? Por que todos não se arribavam à procura de outros lugares e trabalhos? (EVARISTO, 2017, p. 17).

Góes e Florentino (2004), apontaram que durante a escravidão, havia uma regra para as crianças escravas, aproximadamente, aos 12 anos de idade, o "adestramento" que tornavam as crianças escravas adultas já estava se concluindo, pois dos 4 aos 11 anos ela aprendia como ofício, o de ser escravo: "[...] o trabalho era o campo privilegiado da pedagogia senhoril". (GÓES; FLORENTINO, 2004, p. 185).

As humilhações como aquelas que o pai de Ponciá passara, ser feita de besta ou cavalo, abrir a boca para que o coronelzinho urinasse dentro, a dúvida de sua capacidade de aprender ler e escrever, etc., eram resultados da "escola da escravidão", pois desde muito cedo o filho do patriarca "recebia" uma criança escrava, com a qual crescia, e travava uma relação para além da amizade e da companhia, pois servia como seu brinquedo.

O pai de Ponciá aprendera a ler as letras numa brincadeira com o sinhô-moço, que numa ocasião ficara curioso para ver se o negro aprendia os sinais, as letras de branco, e começou a

Anu. Lit., Florianópolis, v. 24, n. 2, p. 42-58, 2019. ISSNe 2175-7917 
ensinar seu pajem: "Negro aprendia sim! Mas o que o negro ia fazer com o saber de branco? O pai de Ponciá Vicêncio, em matéria de livros e letras, nunca foi além daquele saber". (EVARISTO, 2017, p. 18).

Luandi, o irmão de Ponciá, como já relatado, não frequentou a escola, mas nunca perdeu o desejo de aprender a ler e escrever para um dia se tornar soldado, e seu sonho era que no dia em que isso acontecesse, voltaria à Vila Vicêncio para buscar a mãe. Na cidade, ele observou que negros também podiam ser soldado e mandar, não somente obedecer, como seu pai e avô. Nesse caso, a narrativa traz um ímpeto de superação e confere protagonismo ao negro que busca melhores condições de acesso à cidadania. No final do livro, ele afirma que não bastava saber ler, escrever e assinar o nome, sim precisava construir a história dos seus.

Petronilha Gonçalves e Silva (2016) afirmou que as disparidades sociais e educacionais têm sido constitutivas da sociedade brasileira, uma vez que há quatro séculos têm sido edificadas relações étnico-raciais que segregam social e educacionalmente os negros. Sobre a população escravizada, pouco se sabe sobre seu processo de escolarização, no entanto, negar que existia escravizados letrados, é uma das estratégias deliberada ou ingenuamente utilizadas para negar sua humanidade. O pai de Ponciá, ao afirmar enfaticamente que "negro aprendia sim", e o irmão ao se esforçar e a aprendizagem da leitura, confere humanidade, capacidade e ensejo de aprender a cultura letrada que não deveria ser exclusividade do branco.

\section{O sobrenome Ponciá}

A história do sobrenome Vicêncio possui relação direta com a de seus antepassados, pai e avô. Como apontou Duarte (2006), desde o início do livro a personagem emerge despojada de seu nome de família, pois o "Vicêncio" usado como sobrenome, provém do antigo dono das terras, o Senhor Vicêncio:

Quando mais nova, sonhara até um outro nome para si. Não gostava daquele que lhe deram. Menina, tinha o hábito de ir a beira do rio e lá, se mirando nas águas, gritava o seu próprio nome. Ponciá Vicêncio! Ponciá Vicêncio! Sentiase como se estivesse chamando outra pessoa. Não ouvia o seu nome responder dentro de si. Inventava outros. (EVARISTO, 2017, p. 18).

Conforme Eduardo Assis Duarte (2006), essa marca de subalternidade, que denuncia a ausência entre os remanescentes de escravos e dos mínimos requisitos de cidadania, estende-se pelo penoso circuito de vazios e derrotas, no qual tanto a menina quanto a mulher vão sendo alijadas dos entes queridos e de tudo o que possa significar enraizamento identitário.

Hebe Mattos de Castro (2001), apontou que o período que vai desde o final do século XVIII até a Lei Áurea no Brasil foi marcado pela mais ampla transformação social nas américas. Nas sociedades vistas como tradicionais, o privado se contrapunha ao público, ou seja, um jogo de forças que antes do direito, se visa o poder, e era este mecanismo que colocava os senhores tendo sob a guarda seus escravos, essa era a ordem escravista.

Ainda conforme a autora, a união entre a Igreja e o Estado Imperial, por conseguinte a aceitação do catolicismo como religião universal, fez com que o órgão público se redimisse das 
suas responsabilidades para com seus cidadãos, durante quase todo o século, o registro civil não foi a forma de identificação legal dos cidadãos, mas foi mantida a prática dos livros eclesiásticos.

Essa concepção de direito civil e natural de base monárquica e católica foi herdada do Império português, apresentando ainda claras ligações com uma concepção patrimonial do direito e da vida em sociedade. Apesar disso, a continuidade da escravidão na jovem monarquia se fez fundamentada no direito positivo: o direito de propriedade dos senhores sobre seus escravos, assinalados, juridicamente, a simples mercadoria. (CASTRO, 2001, p. 341).

Como pensava sempre Ponciá, seu sobrenome era como "lâmina afiada a torturar-lhe o corpo". Os escravizados ou ex escravizados assumiam como sobrenome o nome de quem fora seu dono, isso significou um complexo processo de consolidação identitária, que mistura uma relação de submissão e ao mesmo tempo o sobrenome poderia oferecer o sentimento de pertença a um mesmo grupo, comunidade, reforçando os laços de parentesco que possuíam no cativeiro.

Ponciá Vicêncio sabia que o sobrenome dela tinha vindo desde antes do avô de seu avô, o homem que ela tinha copiado de sua memória para o barro e que a mãe não gostava de encarar. O pai, a mãe, todos continuavam Vicêncio. Na assinatura dela a reminiscência do poderio do senhor, um tal Coronel Vicêncio. (EVARISTO, 2017, p. 26).

Castro (2001) ainda aponta que muitos senhores almejavam a manutenção da ascendência moral sobre seus escravos, o objetivo era conservar os ex-escravos nas fazendas e continuar ordenando seus atos, contendo assim a revolta que poderiam causar. Os ex-senhores apostavam na gratidão e na força dos laços de família e vizinhança desenvolvido pelos libertos ainda durante a escravidão.

\section{Considerações finais: Ponciá Vicêncio, o reencontro com sua ancestralidade}

Como podemos observar, a jornada de Ponciá Vicêncio não é algo fácil e simples de ser explicado. No final do livro, ela consegue reencontrar sua mãe, Maria, que relutantemente havia também feito sua travessia à cidade em busca de seus filhos; e o irmão Luandi, já soldado, seu pai havia falecido antes dela ir para a cidade.

Todos os reencontros ocorreram na estação de trem de onde chegavam os moradores do povoado Vicêncio, ali tinha chegado primeiramente Ponciá, depois Luandi e, por fim, Maria. E este foi o primeiro lugar que Luandi cumpriria sua função de soldado, finalmente viveria aquele lugar de outro modo, não era mais um migrante, sim alguém que já pertencia aquele espaço.

E, apesar de a estação ser pequena, a Luandi pareceu que uma distância de séculos se impunha entre ele e a mulher-miragem. Silhueta ao longe, que demorava infinitamente a se concretizar diante dele. E, sem conseguir dar um passo em direção ao que precisava alcançar, só a voz dele mexeu gritando um nome. O nome de Ponciá Vicêncio ecoou na estação como um apito do trem e ela nem prestou atenção ao chamado. Andava, chorava e ria dizendo que queria voltar ao rio. Luandi acercou-se carinhoso da irmã dizendo-lhe que 
sabia o caminho do rio e que haveria de levá-la. Ponciá Vicêncio levantou os olhos para ele, mas não podia dizer se ela havia reconhecido ou não. Abriu, porém, a trouxa, tirou o homem-barro e perguntou ao irmão se ele se lembrava de Vô Vicêncio. Ele, que, até então, à custa de muito esforço, tinha o pranto preso, abraçou chorando a irmã. (EVARISTO, 2017, p. 106).

Maria José Somerlate Barbosa (2017), aponta no posfácio da obra de Evaristo, que a ternura é uma forma de redenção, de quase todas personagens, que trazem complexidades imensas, e não podem ser classificadas como simplesmente boas ou más, mesmo as mais periféricas. O marido de Ponciá, que violentava a esposa frequentemente, a fim de resgatá-la de sua inanição, o avô Vicêncio, que matara a esposa, só não matou o filho porque ele foge, e decepou seu braço, trazem consigo a marca de um Brasil desigual, tolerante com a exploração do trabalhador, com o coronelismo e indiferente aos pobres, mesmo sustentando preceitos cristãos.

As mulheres, ressalta Barbosa (2017), são descritas como fortalezas de espírito e de corpo, são fontes de mudanças sociais. Ponciá, mesmo tendo perdido os sete filhos que engravidou, supera a dor e se conforma com a situação, mas isso não fazia dela um indivíduo sem herdeiros, que estavam representados pelas suas peças de barro, que marcaria a eternidade e a resistência dos Vicêncios no mundo. O cheiro do barro jamais sairia de suas mãos.

"A vida era um tempo misturado do antes-agora-depois-e-do-depois-ainda. A vida era a mistura de todos e de tudo. Dos que foram, dos que estavam sendo e dos que viriam a ser". (EVARISTO, 2017, p. 110).

Ponciá consegue heroicamente realizar o reencontro consigo, e finalmente o romance desvenda a herança que muitos haviam prometido que o avô lhe deixara: o rio, o barro, e sua missão de reunir com os pedaços de barro a história de seu povo, sua ancestralidade.

A cultura do Atlântico Negro teorizada por Paul Giroy (2001), cujo caráter híbrido não se encontra circunscrita às fronteiras étnicas ou nacionais, necessariamente deve ser analisada a partir da experiência da escravidão moderna e sua herança racializada pelo atlântico. Nas palavras do autor:

As culturas expressivas desenvolvidas na escravidão continuam a preservar em forma artística as necessidades e desejos que vão muito além da mera satisfação de desejos materiais. Em oposição à superposição do Iluminismo de uma separação fundamental entre a arte e vida, essas formas expressivas reiteram a continuidade entre arte e vida. Elas celebram o enraizamento estético em outras dimensões da vida social. (GIROY, 2001, p. 129).

Vida e arte estão interligadas na singularidade da existência de Ponciá Vicêncio e de sua família. As vozes, os choros e as revoltas que foram por muito tempo sufocadas durante as infâncias das personagens, tomam espaço nessa nova ordem simbólica, e confere a possibilidade de enunciar seus sofrimentos, dores, amores e principalmente a experiência que transita de pessoa para pessoa de forma artesanal. 


\section{Referências}

ABRAMOWICZ, Anete. A pesquisa com crianças em infâncias e a sociologia da infância. In: FARIA, Ana Lúcia G.; FINCO, Daniela (Org.). Sociologia da infância no Brasil. Campinas: Autores Associados, 2011, p. 17-36. (Coleção polêmicas do nosso tempo; 102).

ABREU, Martha. Slave Mothers and Freed Children: Emancipation and Female Space in Debates on the 'Free Womb' Law, Rio de Janeiro, 1871. Journal of Latin American Studies, Cambridge, v.28, n.3, p.567-580, 1996.

ARIZA, Marília B. A. Mães libertas, filhos escravos: desafios femininos nas últimas décadas da escravidão em São Paulo. Revista Brasileira de História. São Paulo, v. 38, n. 79, p. 151171, dez. 2018.

BARBOSA, Maria José Somerlate. Posfácio a Ponciá Vicêncio. In: EVARISTO, Conceição. Ponciá Vicêncio. Rio de Janeiro: Pallas, 2017. p. 113-118.

BENJAMIN, Walter. Reflexões sobre a criança, o brinquedo e a educação. São Paulo: Duas Cidades, 2002.

BENJAMIN, Walter. O narrador: considerações sobre a obra de Nikolai Leskov. In: BENJAMIN, Walter. Magia e técnica, arte e politica: ensaios sobre literatura e história da cultura. São Paulo: Brasiliense, 1994, p. 197-221.

CASTRO, Hebe Mattos de. Laços de família e direitos no final da escravidão. In: ALANCASTRO, Luiz Felipe (Org.). História da vida privada no Brasil Império: a corte e a modernidade nacional. São Paulo: Companhia das Letras, 2001, p. 337-384.

DUARTE, Eduardo de Assis. O Bildungsroman afro-brasileiro de Conceição Evaristo. Revista Estudos Feministas, Florianópolis, v. 14, n. 1, p. 305-308, abr. 2006.

DUARTE, Eduardo de Assis. Na cartografia do romance afro-brasileiro, Um defeito de cor, de Ana Maria Gonçalves. In: TORNQUIST, Carmen S. et al. (Org). Leituras de resistência: corpo, violência e poder. Florianópolis: Mulheres, 2009, p. 325-348.

EVARISTO, Conceição. Ponciá Vicêncio. Rio de Janeiro: Pallas, 2017.

FANON, Frantz. Pele negra, máscaras brancas. Salvador: EDUFBA, 2008.

FONSECA, Marcus Vinícius da. A educação da criança escrava nos quadros do escritor Joaquim Manoel de Barros. Educação e Realidade, Porto Alegre, v. 36, n. 1, p. 231-251, jan./abr., 2011.

GIROY, Paul. O Atlântico Negro. Modernidade e dupla consciência. São Paulo, Rio de Janeiro: Editora 34/Universidade Cândido Mendes - Centro de Estudos Afro-Asiáticos, 2001.

GÓES, José Roberto; FLORENTINO, Manolo. Crianças escravas, crianças dos escravos. In: PRIORE, M. Del. História das crianças no Brasil. São Paulo: Contexto, 2004, p.177-191.

GOUVÊA, Maria Cristina. A construção do "infantil" na literatura brasileira. Revista Teias, Rio de Janeiro, v. 1, n. 1, p. 1-13, 2000. 
IANNI, Octavio. Literatura e consciência. Estudos Afro-asiáticos, Rio de Janeiro, n. 15, p. 208217, jun. 1988.

MAAS, Wilma Patrícia. O cânone mínimo: o bildungsroman na história da literatura. São Paulo: Editora Unesp, 2000.

MATA, Anderson L. N. Infância na literatura brasileira contemporânea. Estudos De Literatura Brasileira Contemporânea, Brasília, n. 46, p. 13-20, jul./dez. 2015.

MATTOSO, Kátia Q. O fillho da escrava: em torno na lei do ventre livre. Revista Brasileira de História, São Paulo, v. 8, n. 16, p. 37-55, mar./ago. 1988.

MAZZARI, Marcus Vinícius. Romance de formação em perspectiva histórica: o tambor de lata de Günter Grass. São Paulo: Ateliê Editorial, 1999.

MOTT, Maria Lúcia de Barros. A criança escrava na literatura de viagens. Cadernos de Pesquisa, São Paulo, n. 31, p. 57-68, 1979.

PRIORE, Mary Del. Apresentação. In: PRIORE, Mary Del; PINSKY, Carla B. (Org). História das mulheres no Brasil. São Paulo: Contexto, 2013.

SILVA, Petronilha Beatriz Gonçalves e. Apresentação. In: FONSECA, Marcus Vinícius Fonseca; BARROS, Surya Aaronovich Pombo de (Org.). A história da educação dos negros no Brasil. Niterói: EdUFF, 2016, p. 7-10.

\section{NOTAS DE AUTORIA}

Elisângela da Silva Santos (licass20@gmail.com) é professora de Sociologia e Fundamentos da Unidade Acadêmica Especial de Educação da Universidade Federal de Goiás/UFG-Jataí. Doutora em Ciências Sociais pela Universidade Estadual Paulista/FFC-Marília. Pesquisa temas ligados à Sociologia da Infância, ao Pensamento Social Latino-Americano e à Literatura.

\section{Como citar esse artigo de acordo com as normas da revista}

SANTOS, Elisângela da Silva. Pelos fios da memória: infância e ancestralidade em "Ponciá Vicêncio". Anuário de Literatura, Florianópolis, v. 24, n. 2, p. 42-58, 2019.

\section{Contribuição de autoria}

Não se aplica.

\section{Financiamento}

Não se aplica

\section{Consentimento de uso de imagem}

Não se aplica.

Aprovação de comitê de ética em pesquisa

Não se aplica.

\section{Licença de uso}


Este artigo está licenciado sob a Licença Creative Commons CC-BY. Com essa licença você pode compartilhar, adaptar, criar para qualquer fim, desde que atribua a autoria da obra.

\section{Histórico}

Recebido em: 30/03/2019

Aprovado em: 28/08/2019

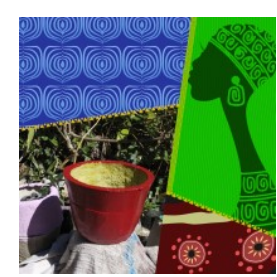

